\title{
Strength, Sustainability and affordability of Bamboo and Mud Bricks as Materials used in Local Construction
}

\author{
Mbereyaho Leopold $^{1 *}$, Mutabaruka Jean de Dieu ${ }^{1}$, Abaho G. Gershome ${ }^{1}$, Ineza Armel ${ }^{1}$, Ngirabatware Ezra ${ }^{1}$ \\ ${ }^{1}$ University of Rwanda, College of Science and Technology, P.O Box: 3900 Kigali-Rwanda. \\ *Principal author email:Imbereyaho2015@gmail.com
}

\begin{abstract}
The construction industry is one of the rapidly growing and the cost analysis suggests that the materials cost is constantly increasing. The continuous extraction of aggregates intensively used in the field is negatively acting to the environment. Therefore research in construction materials should focus not only on discovering new alternative materials but also in appreciating the quality of those locally available for their better application. This research aimed at evaluating the performance of bamboo and mud bricks as two available local building materials, especially with regards not only to their strength but also to new performance concepts which are affordability, energy efficiency and environment friendly aspects. The study comprised mainly of laboratory tests of used materials and cost estimation analysis. Study results established that the considered bamboo and mud bricks, made in ordinary soils and reinforced by sisal fibers were reusable, environment friendly materials and energy efficient, with the bamboo showing the thermal conductivity equal to $0.1496 \mathrm{~W} / \mathrm{mK}$. Regarding the compressive strength, reinforced mud bricks with sisal fibers showed an increased value from 1.75 MPA to 4.29MPA, what was in line with related previous studies. The average compressive strength of the studied Arundinaria Alpine bamboo was established at 133,7MPA, while its tensile strength was 88.16MPA and these values were reasonable with comparison to other conventional materials. It is recommended that further research in checking the performance of other types of bamboo as well as about new construction technologies be undertaken in order to enhance the service life of both bamboo and mud bricks.
\end{abstract}

Key words: Affordability, Bamboo, Conventional concrete, Materials strength, Mud reinforced bricks, Sustainability

\section{Introduction}

As years advance, the building construction industry is growing very fast, and the cost benefit analysis indicates that the materials cost is constantly increasing. Cement has been one of the most used building materials, and the aggressive extraction of its raw components has been gradually conducting to the environment degradation. It is very important that research on construction materials focuses not only on discovering new possible materials that can alternatively be used in building industry, but also in appreciating the quality of those locally available for their better application. In Rwanda there are enough types of soils with which mud bricks are made and then used in construction. Furthermore, two types of bamboo are mostly locally available, Arundinaria Alpina, predominantly found in the north around Volcano National Park and Bambusa vulgaris in the forests of Crest-Zaire-Nile region of the country 
(Ntirugulirwa et al., 2012). Those two materials have been being applied for shelters in rural areas as available and cheaper materials, but had a limited application in the cities, especially due to restricted knowledge about their performance. In this study, bamboo and mud bricks are assessed with consideration of not only their strength characteristics but also new materials requirements concepts, which are sustainability and affordability. Referring to different definitions given in the web, a sustainable material is one that does not deplete non-renewable (natural) resources, and has no adverse impact on the environment when used, while the materials affordability means their state of being cheap or accessible enough for people to be able to buy.

There have been many researches in the past focusing on how to make those materials stronger under given conditions but few were about materials sustainability and affordability.

Zea Escamilla et al. (2018) demonstrated how the adoption of bamboo-based construction systems had a significant potential to support the regenerative development of regions where they could be used and might lead to long-lasting improvements to economies, environments, and livelihoods. On their side, Awalluddin et al. (2017), during their study about mechanical properties of different bamboo species, established that bamboo was suitable to be used as a substitute in place of structural timber in construction, which indirectly would facilitate the preservation of the global environment. In their study about effect of processing methods on the mechanical properties of engineered bamboo, Sharma et al. (2015) concluded that the processing affected the mechanical properties of engineered bamboo products. In other study about engineered bamboo for structural applications, Sharma et al. (2015) concluded that engineered bamboo products had properties that were comparable to or surpass that of timber and timberbased products, and indicated where related further investigation was needed. Another study on mechanical strength properties of bamboo to enhance its diversification on its utilization, concluded that bamboo had proved to be used as an additional material for furniture and constructional works through the tests carried (Gutu, 2013).

In their study on energy efficiency of earth blocks, Mbereyaho et al., (2018) established that the presence of both pozzolana and limestone in the block mix increased not only the compressive strength of the designed block comparing to ordinary mud block and traditionally burnt clay blocks, but also it increased its energy efficiency by $1.6-2.3$ times the energy efficiency of ordinary clay burnt bricks and ordinary concrete block.

Izemmourena and Guettala (2015) in their study about improved durability of compressed earth bricks based on a soil of the region of Biskra, established that the increase of sand concentration improved the earth brick strength. Chaib et al. (2015) conducted a study about thermal study of earth bricks reinforced by date palm fibers and concluded that the introduction of fibers and sand in certain compositions presented the best thermal characteristics. In their study about the strength characteristics of earth bricks and their application in construction, Mbereyaho et al., (2014), established mechanical properties of different local bricks including ordinary and reinforced mud bricks and compared them while suggesting respective area of application.

All other related studies not cited in this work are also appreciated.

The main objective of this study was to evaluate the performance of mud bricks and Bamboo with regard to not only their strength but also their sustainability and affordability, comparing to existing industrial materials such as concrete blocks. The specific objectives were among others, 
to identify and analyze strength characteristics of the two materials, to analyze their sustainability by checking their green level and energy efficiency, and to conduct cost estimation with purpose of establishing their affordability.

\section{Materials and Methods}

\subsection{Bamboo and Sisal fibers Material}

In this study, three years old bamboo available in the mountainous region of Kinigi and called "Arundinaria Alpina", but collected at Masaka incubation center was used (Fig. 1). Sisal fiber is one of the most widely used natural fibers and is very easily cultivated. It is obtained from sisal plant. The used fibers in this study were bought from local market (Fig.2)

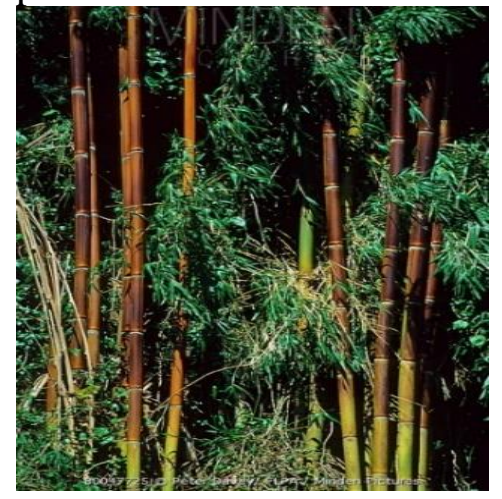

Figure 1: Arundinaria Alpine bamboo;

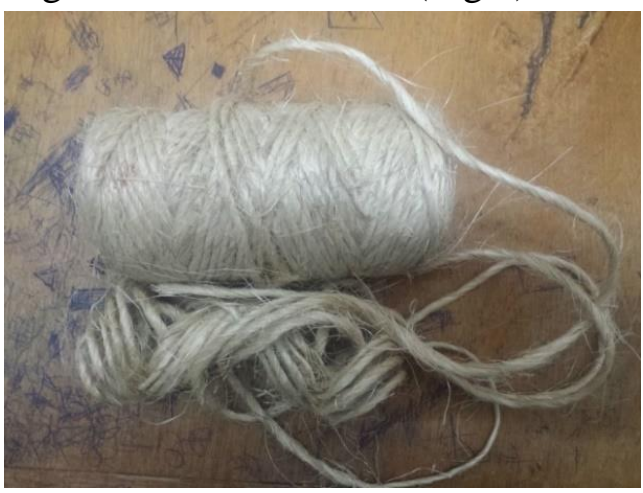

Figure 2: Sisal fibers

The tests carried out with bamboo are described below.

Tensile strength test: The universal testing machine was used. For this test the bamboo gauge length was of $15 \mathrm{~cm}$ before testing.

Compression strength test: A segment of the stem of bamboo was used for compression strength test (Fig. 3). The sample had a diameter of $25 \mathrm{~mm}$ and a cross section of $4.90625 \mathrm{~cm}^{2}$.
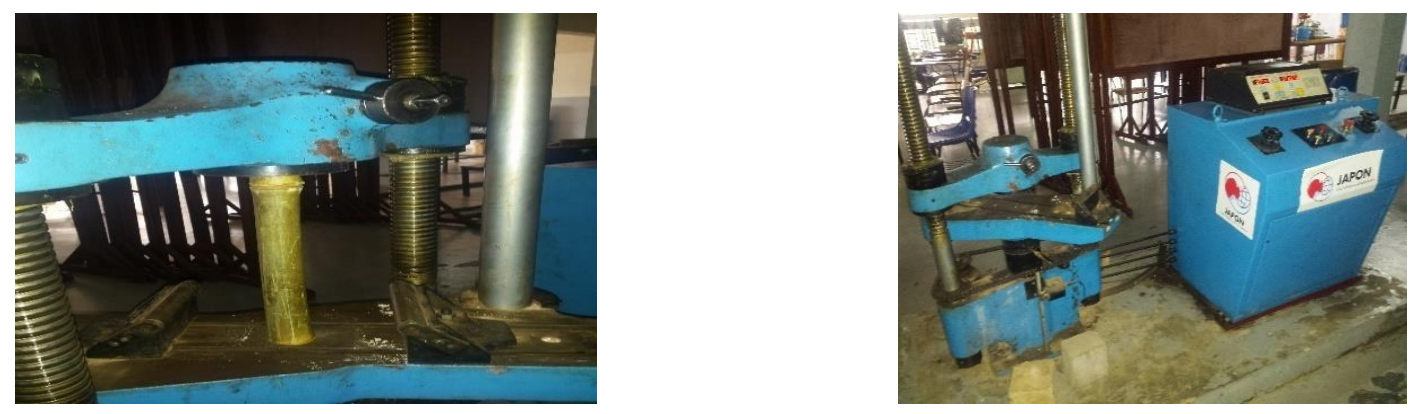

Figure 3: compression test

\subsection{Preparation and tests of mud reinforced bricks}

The used soil: Soil used in this study was collected from Gasabo District site where there was a local construction material for residential houses. Two tests were conducted with the soil: Sieve Analysis and Atterberg Limit Tests. The soil sample of $2269 \mathrm{~g}$ was sieved through $0.4 \mathrm{~mm}$ sieve, and results are presented in the section 3 (Table 2 and Fig.5). After sieve analysis, the Atterberg 
limit test was conducted and the following parameters were determined: plastic limit, liquid limit, and plasticity Index. The Atterberg limit test results are shown in section 3.

Mix proportion for mud brick: Mud bricks reinforced with sisal fibers of different length were used in this study. The table 1 shows the used mix proportion of materials by weight. The soil was sieved through $0.400 \mathrm{~mm}$ sieve.

Table 1: Mixture proportions of mud reinforced bricks

\begin{tabular}{|l|l|l|}
\hline Mixture & Proportion & Relation \\
\hline Soil & $100 \%$ & In relation to the dry mixture \\
\hline Sisal fibers & $10 \%$ & In relation to the soil \\
\hline Water & $5 \%-7 \%$ & In relation to the total mixture \\
\hline
\end{tabular}

The mud reinforced bricks samples are shown in Fig.4 below. 72 dry mud reinforced bricks were tested: 3 bricks for each length of sisal fibers $(0,30,50,60,70,80,90,100 \mathrm{~mm})$.
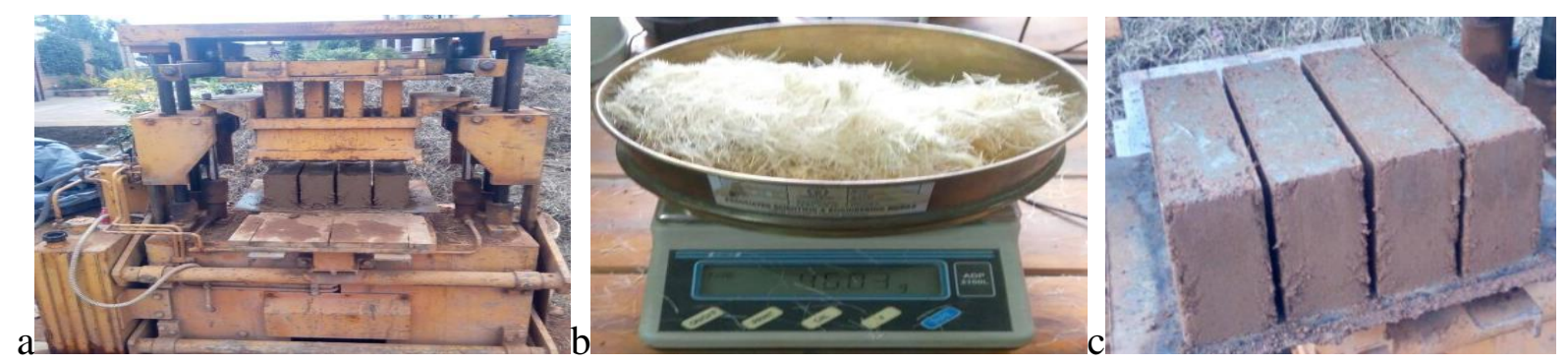

Figure 4: Hydroform machine (a), sisal fibers (b), and Mud reinforced bricks samples (c)

Water absorption and compression Tests of mud bricks: Each sample of bricks, whose weights had been taken in the dry state and noted, was fully immersed into water from the dry oven after $24 \mathrm{hrs}$ of drying. The time taken for full immersion has been noted, and period of twenty-four (24) hours was allowed to elapse. After the 24hours, the wet bricks samples were removed and weighed. The difference between the dry and wet weights of each brick was used to calculate the water absorption capacity expressed in percentage as follows (formula 1):

Absorption capacity $(\%)=\frac{\text { wet weight }- \text { dry weight }}{\text { dryweight ofbrick }}$

Respective results are presented in the section 3 (Table 3 and Fig.6).

The compression test was conducted using compressive testing machine. Samples were tested at 7, 14 and 28 days in dry condition. The average Compressive Strength was calculated using the following formula:

$$
\text { Compressive Strength }=\frac{\text { Maximum Load }}{\text { Cross section area }}
$$


The compressive and tensile strength of Bamboo: the compressive strength is calculated using the following formula:

Compressive strength $($ in $M P A)=\frac{\text { Crushing Load }(M)}{\text { Cross Section Area }\left(\mathrm{mm}^{2}\right)}$

The tensile strength was calculated using the following formula:

Tensile strength $($ in $M P A)=\frac{\text { Forve }(F)}{\operatorname{Area}\left(\mathrm{mm}^{2}\right)}$

The young modulus of bamboo was also calculated and related comparison with other materials conducted.

\subsection{Materials sustainability and affordability aspects analysis}

For materials sustainability, such aspects as energy efficiency and environment impact (reusability or recyclability, embodied energy, and interference to the health of the people) are considered. When determining the building materials affordability, such components as availability, cost of transportation, and cost of production and transformation are checked. Also the heat transfer is established through relevant test, while the thermal conductivity of bamboo is calculated approximately as a function of density as per following formula (5), though precise values will vary according to moisture content (Middendorf, 2001).

$$
k=0.072 \exp \left(1.35 x \frac{\text { density }}{1000}\right)
$$

All respective results are presented in the section 3.

\section{Results}

\subsection{Grading of soil and Atterberg Limit Tests}

The grain size distribution is given in table 2 below, and the sieve analysis grading curve is presented in Fig.5. In the table, Initial Weight $=2,269 \mathrm{gr}$, and the final Weight $=1,656 \mathrm{gr}$

Table 2: Sieve Analysis results

\begin{tabular}{|l|l|l|l|l|}
\hline Sieve $(\mathbf{m m})$ & $\begin{array}{l}\text { Partial } \\
\text { retained }(\mathbf{g r})\end{array}$ & Cumulative retained $(\mathbf{g r})$ & \% Retained & \% Passing \\
\hline $\mathbf{5 . 0 0}$ & 92.00 & 205.00 & 9.03 & 90.97 \\
\hline $\mathbf{4 . 0 0}$ & 127.00 & 332.00 & 14.63 & 85.37 \\
\hline $\mathbf{3 . 1 5}$ & 192.00 & 524.00 & 23.09 & 76.91 \\
\hline $\mathbf{2 . 5 0}$ & 186.00 & 710.00 & 31.29 & 68.71 \\
\hline $\mathbf{2 . 0 0}$ & 179.00 & 889.00 & 39.18 & 60.82 \\
\hline $\mathbf{1 . 0 0}$ & 308.00 & $1,197.00$ & 52.75 & 47.25 \\
\hline $\mathbf{0 . 3 2}$ & 276.00 & $1,473.00$ & 64.92 & 35.08 \\
\hline $\mathbf{0 . 1 6}$ & 158.00 & $1,631.00$ & 71.88 & 28.12 \\
\hline $\mathbf{0 . 0 8}$ & 22.00 & $1,653.00$ & 72.85 & 27.15 \\
\hline $\mathbf{0 . 0 7 5}$ & 3.00 & $1,656.00$ & 72.98 & 27.02 \\
\hline
\end{tabular}




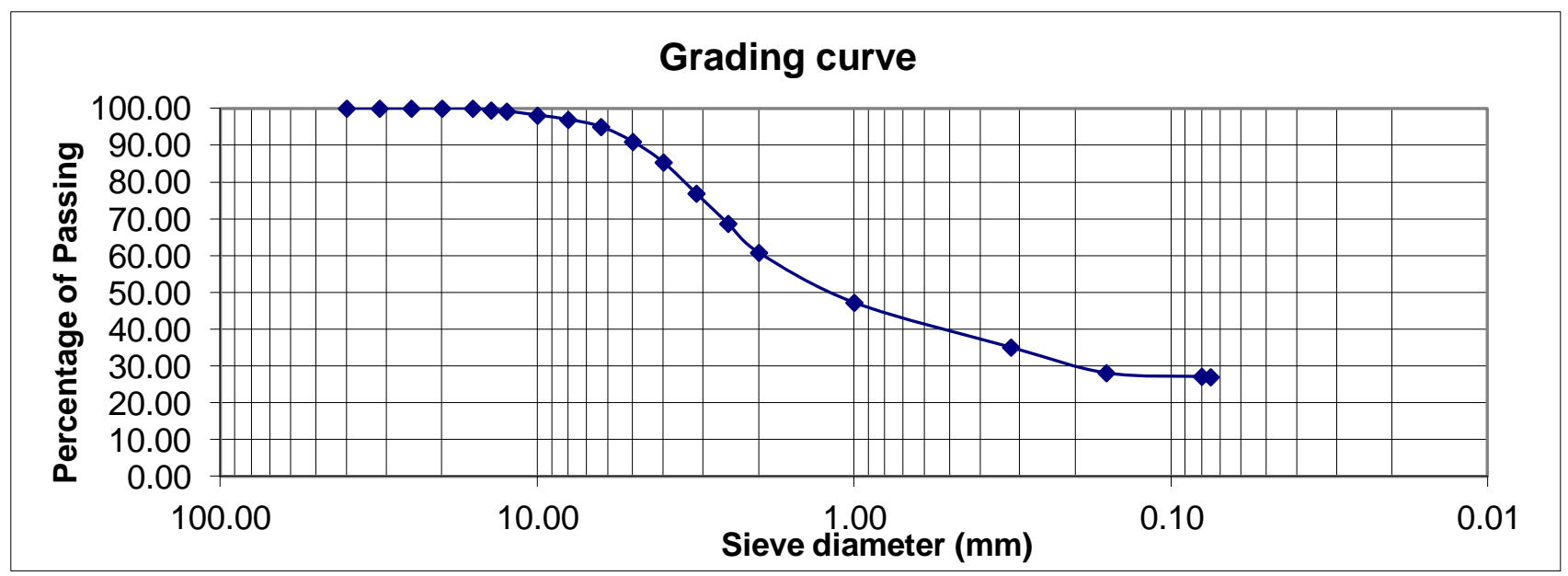

Figure 5: Soil sieve analysis

The Atterberg Limit Tests of the used soil established the following parameters: Liquid Limit: 22.8\%, Plastic Limit: 14.2\%, Plastic index: 8.6\%. Therefore according to AASHTO Classification, the soil is of A-2-4 type (loamy sand).

\subsection{Water Absorption Test}

The results from water absorption test are presented in table 3, while the representative curve is given in Fig.6.

Table 3: tabulated water absorption results

\begin{tabular}{|l|l|l|l|l|l|l|l|l|}
\hline Fiber Length & 0 & 30 & 50 & 60 & 70 & 80 & 90 & 100 \\
\hline Water Absorption (\%) & 8.97 & 8.79 & 8.55 & 8.14 & 7.86 & 7.59 & 7.75 & 7.92 \\
\hline
\end{tabular}

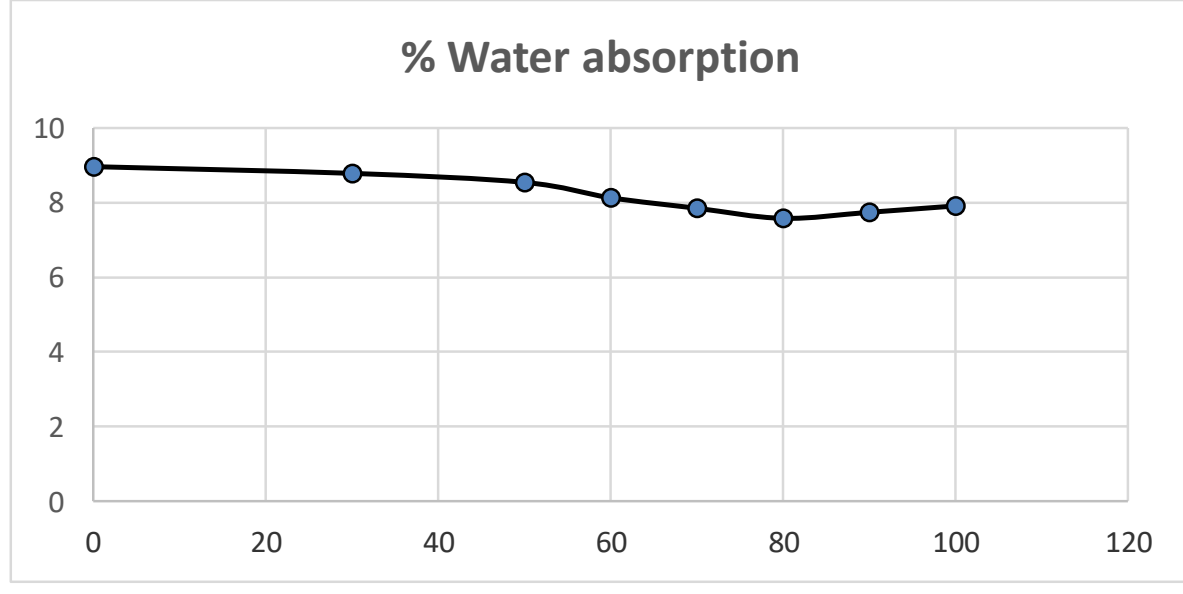

Figure 6: Water absorption

The chart for water absorption of unreinforced and reinforced mud bricks with sisal fibers shows a decrease in water absorption from 8.97 to $7.92 \%$ as the length of reinforced sisal fibers 
increased from 0 to $100 \mathrm{~mm}$. This is explained by the fact that the addition of sisal fibers in the mud brick results in reduction of voids and therefore reduces the absorption of water.

\subsection{Compressive Strength results for mud bricks}

These results are summarized in table 4, presented below.

Table 4: Compressive test results at 7, 14 and 28 days

\begin{tabular}{|c|c|c|c|c|c|c|c|}
\hline Days & Mix & $\begin{array}{l}\text { Fiber length } \\
(\mathrm{mm})\end{array}$ & $\begin{array}{l}\text { Average } \\
\text { Compressive } \\
\text { Strength } \\
\text { (MPa) }\end{array}$ & Days & $\begin{array}{l}\text { Average } \\
\text { Compressive } \\
\text { Strength } \\
\text { (MPa) }\end{array}$ & Days & $\begin{array}{l}\text { Average } \\
\text { Compressive } \\
\text { Strength } \\
\text { (MPa) }\end{array}$ \\
\hline \multirow{8}{*}{7} & 1 & 0 & 1.49 & \multirow{8}{*}{14} & 1.68 & \multirow{8}{*}{28} & 1.75 \\
\hline & 2 & 30 & 2.12 & & 2.39 & & 2.48 \\
\hline & 3 & 50 & 2.71 & & 3.00 & & 3.22 \\
\hline & 4 & 60 & 3.13 & & 3.27 & & 3.46 \\
\hline & 5 & 70 & 3.46 & & 3.68 & & 3.96 \\
\hline & 6 & 80 & 3.84 & & 4.21 & & 4.29 \\
\hline & 7 & 90 & 3.73 & & 4.14 & & 4.21 \\
\hline & 8 & 100 & 3.50 & & 3.77 & & 3.83 \\
\hline
\end{tabular}

The respective chart is presented below in Fig.7 


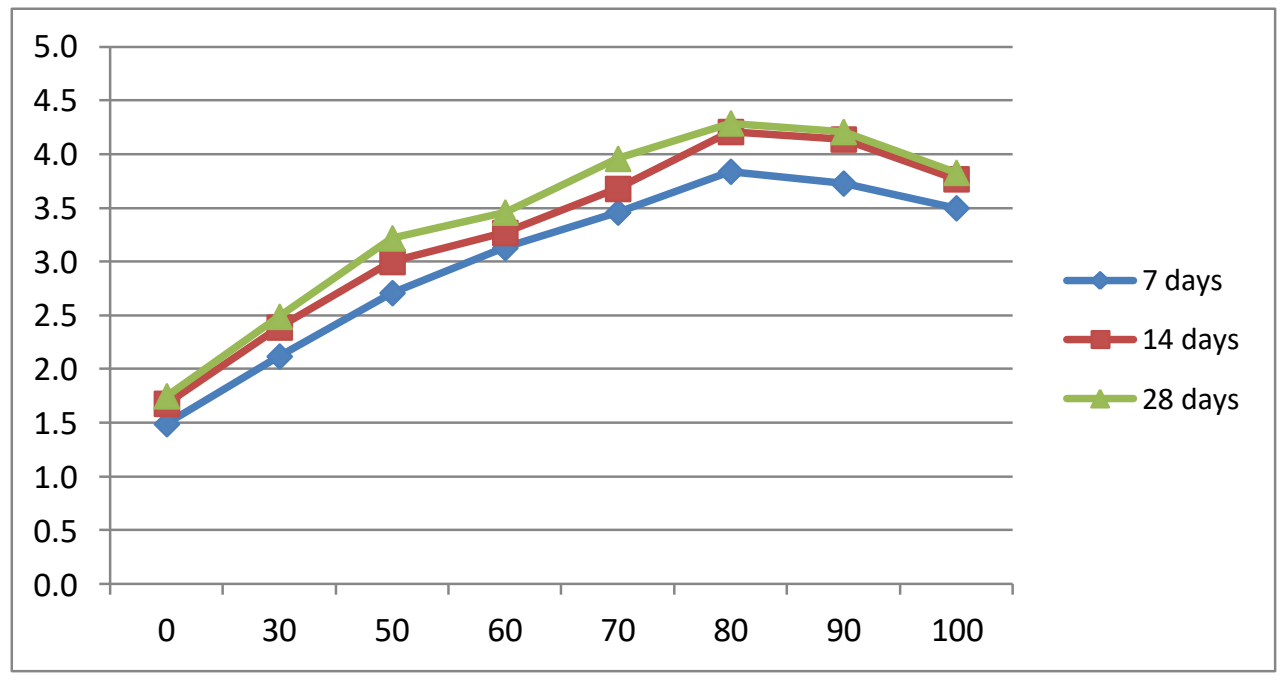

Figure 7: Compressive Strength Results of mud bricks

The average compressive strength of bricks with 80 and $90 \mathrm{~mm}$ sisal fibers recorded the higher strength. It was observed that there was considerable increase in strength for the mud reinforced fiber bricks comparing with the unreinforced mud bricks. The table 4 and Fig.7 show that the increase in sisal length up to $80 \mathrm{~mm}$ increases the compressive strength. Beyond $80 \mathrm{~mm}$, the compressive strength starts decreasing with the increase in sisal fibers length. For example at 28 days, the compressive strength first increased from 1.75 to 4.29 MPA, and then decreased from 4.29 to $3.83 \mathrm{MPA}$, as the length of sisal fibers increased from 0 to $80 \mathrm{~mm}$, and then from 80 to $100 \mathrm{~mm}$.

\subsection{Test with Bamboo Materials}

The compression strength test: The crushing load was $67.54 \mathrm{KN}$; Cross section area was $490.625 \mathrm{~mm}^{2}$. Using the formula (3),

Compressive strength $=\frac{67540 \mathrm{~N}}{490.625 \mathrm{~mm} 2}=133.66 \mathrm{MPA}$

The test result showed that the bamboo compressive strength was 133.66MPA

The tensile strength test: The bamboo gauge initial length was of $15 \mathrm{~cm}$ and after the testing it became $15.1 \mathrm{~cm}$. The recorded maximum load attained was $14.988 \mathrm{KN}$. The dimensions of the sample were: $31.6 \mathrm{~cm} \times 1.7 \mathrm{~cm} \times 1 \mathrm{~cm}$. The stress, strain and the young modulus for the bamboo strip were determined as follows:

Load $=14.988 \mathrm{KN}=14988 \mathrm{~N} ;$ Area $=1.7 \times 1=1.7 \mathrm{~cm}^{2}=170 \mathrm{~mm}^{2} ;$ and Elongation $=15.1-15=0.1 \mathrm{~cm}$ Using the formula (4), the ultimate stress was calculated.

Stress $=\frac{14988}{170}=88.1647 \mathrm{~N} / \mathrm{mm}^{2}=88.1647 \mathrm{MPA}$

Strain $=\frac{\text { elongation }(l-l o)}{\text { initial length }(l o)}=\frac{0.1}{15}=6.6667 \times 10^{-3}$ 
$\mathrm{E}($ Young modulus $)=\frac{\text { stress }}{\text { strain }}=\frac{88.1647}{6.6667 \times 10-3}=13224.705 \mathrm{~N} / \mathrm{mm}^{2}=13224.705 \mathrm{MPA}$

From the performed test results, the young modulus of the Arundinaria Alpina bamboo from Rwanda was found to be 13224.705MPA.

\subsection{Sustainability Analysis}

The environment impact of bamboo was confirmed by the fact that bamboo was a reusable and recyclable material. The bamboo energy efficiency was checked as follows.

Heat transfer test: The results from conducted test with bamboo were used to plot the graphic in Fig. 8 below.

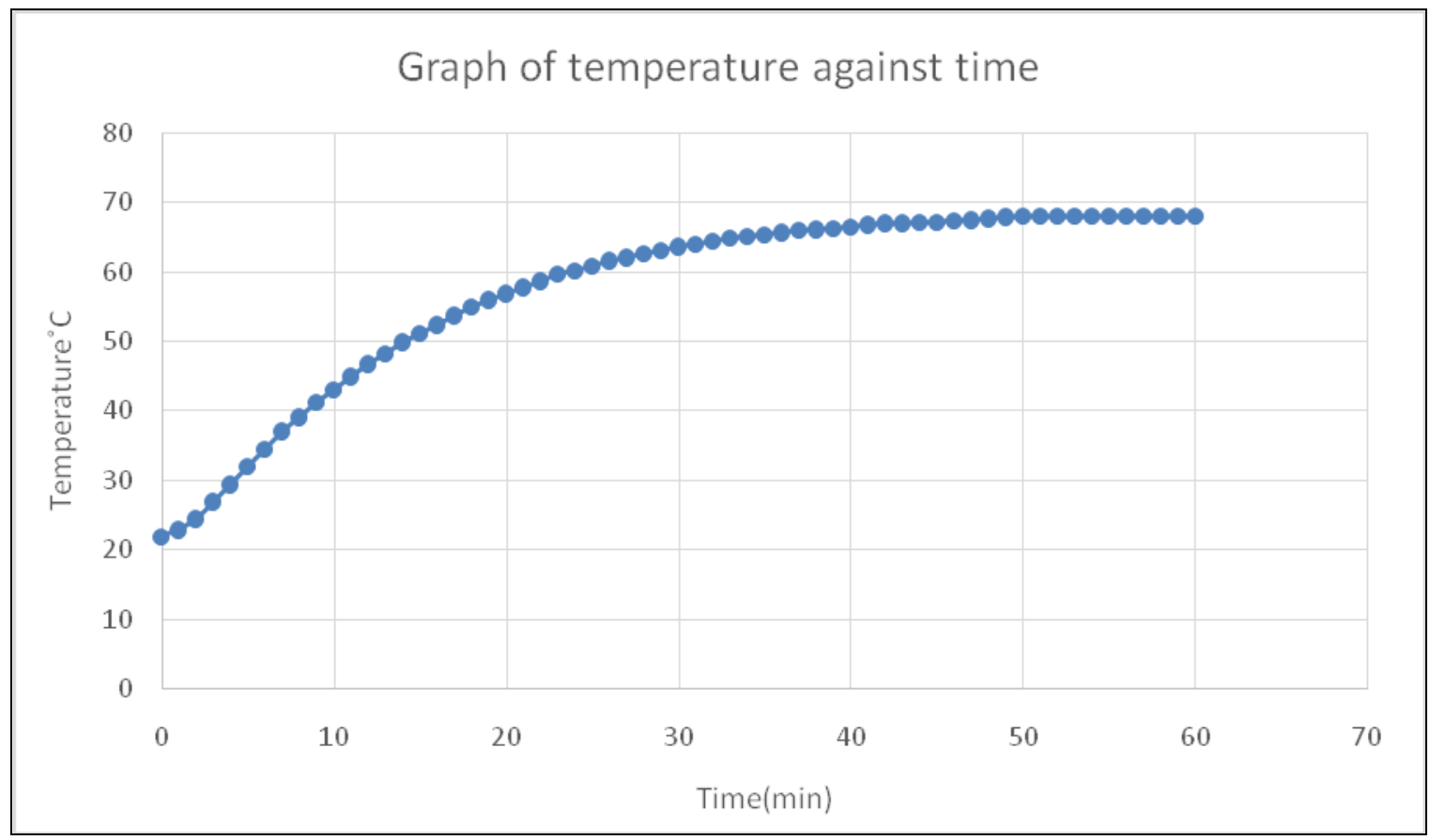

Figure 8: Bamboo heat transfer curve

The above curve shows that the temperature in bamboo increased from initial temperature of $22^{\circ} \mathrm{C}$ to $68^{\circ} \mathrm{C}$ in one hour. It can be observed that the rate of increase in temperature was gradually decreasing with increase of the time, and in the last 10 minutes the temperature looks to remain constant at $68^{\circ} \mathrm{C}$. Therefore it can be assumed that $80^{\circ} \mathrm{C}$ would be the maximum temperature it could attain even if the time would be kept increasing. Using the formula (3), the thermal conductivity of bamboo, $\mathrm{k}$ was also calculated and was found equal to $0.1496 \mathrm{~W} / \mathrm{mK}$.

\subsection{Materials affordability by cost estimation}

The used bamboo which was grown in Kinigi region was $5 \mathrm{~m}$ length and of $3 \mathrm{~cm}$ diameter, and its cost was 400 Rwandan Francs. The cost comparison between bamboos to other materials that can be replaced by bamboo in construction is presented in Table 5. 
Table 5: Comparison costs between materials

\begin{tabular}{|c|c|c|c|c|}
\hline \multirow{2}{*}{$\begin{array}{l}1 \\
S / N\end{array}$} & \multicolumn{4}{|c|}{ Comparison costs between bamboos to other materials } \\
\hline & Material & Cross section $\left(\mathrm{cm}^{2}\right)$ & Length $(m)$ & $\operatorname{Cost}(R w f)$ \\
\hline 1.1 & Bamboo & 28.26 & 5 & 400 \\
\hline 1.2 & Tree (Pinus) & 20 & 3.6 & 1066.667 \\
\hline 1.3 & Mild steel & 40 & 5 & 2666.67 \\
\hline 2 & \multicolumn{4}{|c|}{ Cost analysis of one mud brick with and without fibers } \\
\hline$S / N$ & Type of mud brick & $\begin{array}{l}\text { Materials } \\
\text { components cost }\end{array}$ & Manpower & $\begin{array}{l}\text { Hydraform } \\
\text { Machine }\end{array}$ \\
\hline 2.1 & without fibers & 2 & 6.7 & 10 \\
\hline 2.2 & with fibers & 5 & 10 & 10 \\
\hline \multicolumn{2}{|c|}{$\begin{array}{l}\text { Total cost for MB without Fibers } \\
\text { ( see } 2.1 \text { ) }\end{array}$} & \multicolumn{3}{|c|}{$18.7 \mathrm{Rwf}$ for one mud brick } \\
\hline \multicolumn{2}{|c|}{$\begin{array}{l}\text { Total cost for MB with Fibers (see } \\
\text { 2.2) }\end{array}$} & \multicolumn{3}{|c|}{$25 \mathrm{Rwf}$ for one mud brick } \\
\hline
\end{tabular}

In those cases the Bamboo has a considerable low cost compared to both mild steel and Pinus materials. Also, it can be seen that reinforced mud brick still was more affordable than other conventional materials.

\section{Discussion of results}

\subsection{Strength results}

From the results the following is established:

Reinforced mud bricks with sisal fibers showed a decrease in water absorption as the length of reinforced sisal fibers increases. Also, the reinforcement of mud bricks with sisal fibers has increased the compressive strength of mud bricks from 1.75 MPa to 4.29 MPa. This is confirmed by related previous studies (Mbereyaho L. et.al, 2014)

The average compressive strength of Arundinaria Alpine bamboo (133,7MPA) is greater than the minimum compressive strength of the concrete for such permanent RC elements as reinforced concrete beams, slabs, columns and walls (Neville G.B, P.E, 2015). It is however less than the 
compressive strength of mild steel which is normally between 250-350MPA. The tensile strength of Arundinaria Alpine bamboo was 88.16MPA, that is five times less than the one for mild steel having quite the same cross section (around 440MPA), but eight time greater than the one for conventional optimum concrete estimated at around 4.5MPA. The obtained compressive strength for the studied species was far better, while its tensile strength was less comparing with the same for bamboo in general (Guti T, 2013). From the performed test results, the young modulus of the Arundinaria Alpina bamboo from Rwanda was found to be $13.2 \mathrm{GPa}$. This value is slightly smaller but near the recommended strength for different types of bamboo which should be between 15 and $20 \mathrm{GPa}$ (Cambridge University Engineering Department, Materials Data Book, 2003 Edtion).

\subsection{Sustainability and energy efficiency of materials}

The study established the following results for discussion.

The main ingredients to produce mud reinforced bricks are soil and sisal fibers. Sisal fibers are industrially made and this means the production is not environment friendly. However, the sisal is produced from the plant called "agave sisal" which is naturally growing with a good impact to the environment. Mud soil can be easily returned back into normal soils, and that means it is an eco-friendly material. Therefore, reinforced mud bricks, as composed by sisal fibers and ordinary soils are reusable, energy efficient and environment friendly material. As per environment impact assessment of bamboo, this was considered as an eco-friendly material as it grows well without the use of pesticides or fertilizers, and no chemicals would enter the ground.

Regarding the energy efficiency, while the production of some construction materials such as cement, iron, and aluminum would require high energy, bamboo was a reusable material with embodied energy. The potential maximum temperature to be transferred by Arundinaria Alpina bamboo was estimated at $80^{\circ} \mathrm{C}$, while its thermal conductivity, $\mathrm{k}$ established at $0.1496 \mathrm{~W} / \mathrm{mK}$, meant that the given bamboo was more energy efficient material, comparing to such materials as steel $(12-45 \mathrm{~W} / \mathrm{mK})$ and concrete $\left(\mathrm{k}_{\min }=0.70 \mathrm{~W} / \mathrm{mK}\right)$, and with other bamboo species (M. Mounika, et al., 2012). This value for the studied species was even better comparing to some other oven dry wood materials in general with $\mathrm{k}$ values ranging between 0.41 and $1.19 \mathrm{~W} / \mathrm{mK}(\mathrm{J}$. D. MacLean et al., 1941). Finally, this bamboo thermal conductivity of $0.1496 \mathrm{~W} / \mathrm{mK}$ is quite less than the ones for reinforced and well balanced earth blocks which are between 0.646 and $0.727 \mathrm{~W} / \mathrm{mK}$ (Mbereyaho L. et.al, 2018).

Regarding the affordability, the cost estimated cost of one bamboo and one mud brick were 400 Rwandan francs and 25 Rwandan francs respectively. This is very cheaper when compared to the cost of other conventional building materials and they can be used as replacements.

\section{Conclusions and recommendation}

This study has shown that bamboo which was at least as stronger as other conventional materials was affordable and sustainable material and it can easily replace them where applicable. However, it is very important that bamboo is well treated in order to ensure its durability and mechanical performance (Bui Q-B, 2017), and service life of related structures.

For the mud reinforced bricks, while it is confirmed that these are stronger than ordinary mud bricks, they are still less strong than other type of bricks and blocks. However, they can be used 
for different purpose as they have an acceptable minimum strength, especially for simple wall structures, and they are at the same time affordable and sustainable.

Using the thermal conductivity in assessing and comparing the level of energy efficiency between it can be concluded that the studied bamboo was more energy efficient than not only conventional materials but also than reinforced with grasses and well balanced earth blocks which are between 0.646 and $0.727 \mathrm{~W} / \mathrm{mK}$ (Mbereyaho L. et al, 2018).

Further research may be interested in checking the performance of other types of bamboo, but also in better construction technologies to be used in order to enhance the above materials service life.

\section{References}

Awalluddin D., Mohd Azreen Mohd Ariffin, Mohd Hanim Osman, Mohd Warid Hussin, Mohamed A. Ismail, Han-Seung Lee, and Nor Hasanah Abdul Shukor Lim. Mechanical Properties of Different Bamboo Species. MATEC Web of Conferences 138, 01024 (2017) DOI: $10.1051 /$ matecconf $/ 201713801024$

Bui Q-B., Anne-Cécile Grillet and Hoang-Duy Tran (2017). A Bamboo Treatment Procedure: Effects on the Durability and Mechanical Performance. Sustainability 2017, 9, 1444; doi:10.3390/su9091444.

Cambridge University Engineering Department. Materials Data Book, 2003 Edtion

Chaiba H., Abdelouahed KRIKERa, Abdessalam MEKHERMECHE (2015). Thermal Study of Earth Bricks Reinforced by Date Palm Fibers. International Conference on Technologies and Materials for Renewable Energy, Environment and Sustainability, TMREES15 Energy Procedia 74 : 919 - 925

Gutu T. (2013), A Study on the Mechanical Strength Properties of Bamboo to Enhance Its Diversification on Its Utilization. International Journal of Innovative Technology and Exploring Engineering (IJITEE), Volume-2, Issue -5.

Izemmourena O, Guettala A. (2015). Improved Durability of Compressed Earth Bricks Based on a Soil of the Region of Biskra. MATEC Web of Conferences 11, 02001(2014) DOI: $10.1051 /$ matecconf/20141102001

MacLean, J. D., Madison, Wis (1941), Thermal Conductivity of Wood. Heating, piping \& air conditioning Vol. 13, no. 6, pp. 380-391.

Mbereyaho L., Twubahimana J. D.\& Mureramanzi G.(2014). Strength characteristics of earth bricks and their application in construction. International Research Journal on Engineering, Vol. 2(1), pp. 001-007.

Mbereyaho L., Tubarimo J. B. \& Halera J. (2018), Study on energy efficiency of earth blocks. INES Scientific journal, Volume 13, pp.98 - 114 
Middendorf J. (2001). Properties and Methodology of Earth Structures, GSD 6400: Energy and Environment Michelle Addington. Harvard Graduate School of Design

Mounika M., Ramaniah K., Ratna Prasad A.V., Mohana K. R., Hema K. C. R.(2012), Thermal Conductivity Characterization of Bamboo Fiber Reinforced Polyester Composite. Journal. Mater. Environ. Sci. 3 (6), pp: 1109-1116

Neville G. B., P.E (2015). Concrete Manual: Based on the 2015 IBC® and ACI 318-14. COPYRIGHT (C) 2015, International Code Council.

Ntirugulirwa B., Asiimwe T., Gapusi J., Mutaganda A., Nkuba G. , Ruzindana N.A., Ntabana D., Bizeye B., Kahia J., and Daphrose Gahakwa (2012). Influence of Bud Position on Mother Stem and Soaking Duration on Sprouting of Bamboo Cuttings. Rwanda Journal, Volume 28, Series E: Agricultural Sciences

Sharma B., Gatóo A., Ramage M. H. (2015). Effect of Processing Methods on the Mechanical Properties of Engineered Bamboo. Construction and Building Materials 83 (2015), 95101

Sharma B., Ana Gatóo, Maximilian Bock, Michael Ramage (2017). Engineered bamboo for structural applications. Construction and Building Materials, Volume 81, 15 April 2015, Pages 66-73. https://doi.org/10.1016/j.conbuildmat.2015.01.077

Zea Escamilla E., Habert G., Correal Daza J. F., Hector F. Archilla , Echeverry Fernández J. S., and Trujillo D. (2018). Industrial or Traditional Bamboo Construction? Comparative Life Cycle Assessment (LCA) of Bamboo-Based Buildings. Sustainability 2018, 10, 3096; doi:10.3390/su10093096 